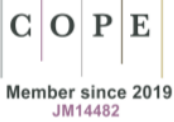

Jean-Marie Barbier*

Ewa Marynowicz-Hetka**

\title{
„Myśląc transformacje” - wprowadzenie w problematykę
}

\begin{abstract}
Abstrakt
Tekst przedstawia zawartość numeru tematycznego poświęconego refleksji nad zagadnieniem „myśleć transformacje”, związanym z procesami profesjonalizacji i w sposób bardziej ogólny także z powiązanymi wzajemnie transformacjami aktywności oraz podmiotów przebiegającymi w ich aktywnościach i poprzez nie.
\end{abstract}

Słowa kluczowe: transformacje, myśleć transformacje, profesjonalizacja, praca zespołowa.

\section{“Thinking Transformations" - an Introduction to the Issues}

\begin{abstract}
The text presents the content of the thematic issue devoted to the reflection on the issue of "thinking transformations", related to the processes of professionalization and, more generally, to the interrelated transformations of activities and entities occurring in and through their activities.
\end{abstract}

Keywords: transformations, thinking transformations, professionalization, teamwork.

„Panta rei”, wszystko płynie, jak mówi Heraklit. To sformułowanie, od początków istnienia kultury zachodniej, charakteryzującej się podejściem do rozumienia świata w kategoriach „prowizorycznie ustabilizowanych obiektów myśli” (Jullien 2009: 17-21; Jullien 2017: 181-185), może stanowić pierwszą charakterystykę labilności i stałej transformacji różnych środowisk, w których ludzie żyją i działają.

* Conservatoire National des Arts et Métiers, Chaire Unesco - ICP, Paris, France.

** Uniwersytet Łódzki. Polska.

Artykuł otrzymano: 18.06.2021; akceptacja: 22.06.2021. 
Ta sama intuicja towarzyszy również historii współczesnej nauki. Antoine Lavoisier, jeden z autorów ważny dla konstytuowania takiej dyscypliny jak chemia, przyznaje, że „nic się nie tworzy ani w operacjach sztucznych, ani w operacjach przyrody, można przyjąć zasadę, że w całej operacji ta sama ilość materii istnieje przed i po operacji (...) i, że jakość i ilość początków (tzn. pierwiastków) jest ta sama i występują jedynie zmiany, modyfikacje" (Lavosier 2001: 85).

Redaktorzy i autorzy tego numeru formułują hipotezę, że współczesne przemiany $w$ profesjonalizacji, odbijające się także w kształceniu wyższym, mogą reaktywować wszystkie pytania dotyczące statusu transformacji w związkach człowieka ze światem i z sobą samym, żyjącym i działającym. Niektóre z tych kwestii sygnalizujemy poniżej.

Różne środowiska społeczne przekształcają się w sposób ciągły. Dotyczy to również nauk o ziemi, które przyjmują za swój przedmiot kategorię transformacji i formułują hipotezy odnoszące się do zmian, wprawdzie wolniejszych, ale fundamentalnych dla zrozumienia stanu świata, na który rzekomo oddziałujemy.

Wiele aktywności ludzkich można analizować jako aktywności transformacji świata, wyodrębniając obiekty, na które one starają się oddziaływać, co sprzyja pomieszaniu „wszystkiego ze wszystkim”: dyscyplin przygotowujących do zawodu (techniczne, zajmujące się projektowaniem zmian) i dyscyplin akademickich (zwłaszcza nauk ścisłych) przyjmujących jako przedmiot poznania obiekty transformacji.

Wraz z rozwojem aktywności trzeciego sektora (la tertiarisation) i rozwojem zawodów społecznych (métiers de l'humain) duża liczba dyscyplin przyjmuje transformację podmiotów w aktywności jako swój przedmiot badań. Dotyczy to np.: nauk o wychowaniu, nauk o komunikacji, nauk o zarządzaniu, interwencji społecznej etc.

Wreszcie, przekształcając świat, podmioty ludzkie przekształcają siebie samych, ale te transformacje są najczęściej bezszelestne (silencieuses).

Przygotowaliśmy ten numer tematyczny w rezultacie skrzyżowania dwu kultur myślenia, w trakcie wieloletniej współpracy między dwoma zespołami: polskim (Uniwersytet Łódzki i powiązanymi z nim autorami z Akademii Pomorskiej w Słupsku oraz Uniwersytetu w Białymstoku) i francuskim (Conservatoire National des Arts et Métiers - Formation et Apprentissages Professionnels i Katedry UNESCO Instytutu Katolickiego w Paryżu Formation Professionnelle, Construction personnelles et Transfomations sociales).

Przedmiotem tekstów zgromadzonych w tym numerze jest eksploracja różnych aspektów epistemologicznych, teoretycznych, metodologicznych i społecznych odnoszących się do tego, co można określić jako „myślenie transformacyjne”, w szczególności gdy odnosi się ono do zagadnień działania i kształcenia profesjonalnego.

W przeciwieństwie do zwyczajowego postępowania i przyzwyczajeń intelektualnych stawiamy następujące skomplikowane pytania (épineuses questions): 
- jak funkcjonuje podejście dynamiczne, w którym przyjmuje się w życiu dominację „przepływu”?

- w jakie narzędzia należałoby wzbogacić/wyposażyć podejście kontekstualne, przyjmując, że sens działania konstytuuje się w sposób lokalny i temporalny?

- czy można mówić o prymacie praktyki nad teorią?

- jak myśleć o symultanicznych transformacjach organizmów, podmiotów i procesów, takich jak: postrzeganie, wyobrażanie, osądzanie i rozumowanie?

- jak pojąć aktywność w trakcie jej trwania?

Propozycje odpowiedzi zawarliśmy w piętnastu artykułach, zgrupowanych w trzech częściach numeru tematycznego: Studia i rozprawy, Prace z warsztatu; Dyskusje/polemiki/recenzje. W pierwszej części znajdują się artykuły, które analizują różne aspekty paradygmatu transformacji:

- Jean-Marie Barbier mówi o wzajemnych (pożenionych) związkach między działaniem profesjonalnym a tym, co określa się jako „myślenie transformacyjne";

- Ewa Marynowicz-Hetka omawia postrzeganie koncepcji analizy transwersalnej aktywności, opracowanej przez Jeana-Marie Barbiera (2016), z punktu widzenia pedagogiki społecznej i proponuje paradygmat transformacji;

- Lech Witkowski, w szerokiej perspektywie filozoficznej przedstawia koncepcję transformacji, podkreślając dominanty tego procesu i specyficzność przestrzeni między dynamiką a strukturą procesualności;

- Anna Walczak, odnosząc się filozofów francuskich, analizuje zagadnienie tożsamości podmiotu działającego, podkreślając kategorię różnicy.

W drugiej części numeru umieściliśmy artykuły, które zostały przygotowane na podstawie badań jakościowych, ściśle mówiąc materiałów narracyjnych, analizy dyskursu, obserwacji etnograficznej. Podejmują one analizę dynamik aktywności oraz analizę procesów transformacji w trakcie działania. Tak więc, treść tych artykułów obejmuje dwa zjawiska usytuowane w różnych przestrzeniach: transformacje i oddziaływania, odnosząc się często do konceptów aktywności i transformacji Jeana-Marie Barbiera i innych badaczy z tego nurtu epistemologicznego. Przestrzenie analizy dotyczą przede wszystkim sfery profesjonalnej osób, które wykonują zawody/profesje społeczne w: sektorze zdrowia (Martine Dutoit), działalności związków zawodowych (Marie Jasmine Hyppolite), policji (Myriam Leonard), organizacji pozarządowych/trzeciego sektora (Daniela Rodriguez), przedsiębiorstw (Kim Vu), aktywności asystentów rodziny (Izabela Kamińska-Jatczak) i także sfery prywatnej rodziny (Katarzyna Gajek).

W trzeciej części numeru zaproponowaliśmy artykuły, które podejmują dyskusję lub polemiki z konceptami omawianymi w tym numerze. Są tam artykuły:

- przygotowane na podstawie spotkań i analizy dyskursu opisującego okoliczności przepływu intelektualnego między naszymi kulturami myślenia (francuskiej i polskiej) (Marcin Kafar, Ewa Marynowicz-Hetka); 
- rzucające światło na koncepcję analizy transwersalnej aktywności (Barbier 2016), postrzeganą jako znaczące doświadczenie badawcze (Izabela Kamińska-Jatczak);

- pokazujące możliwości zastosowania narzędzi analizy aktywności (Barbier 2016), kiedy przedmiotem namysłu staje się twórczość i towarzyszące jej emocje, tworzące przestrzeń transformacji i synergii (Halina Monika Wróblewska);

- będące efektem lektury (Lech Witkowski) pracy zespołowej Représenter/transformer (Barbier, Durand 2018), podkreślającej transwersalne ujęcie związków między reprezentacjami i transformacjami.

W końcowej części numeru, zatytułowanej Aktualności proponujemy czytelnikom dwa krótkie teksty:

- pierwszy, przygotowany przez Jeana-Marie Barbiera i Martine Dutoit, na temat projektu badawczego „Se préparer à l'action” [Przygotować się do działania], aktualnie realizowanego przez Katedrę UNESCO (Chaire Unesco à l'Institut Catholique de Paris), zorientowanego na liczną grupę partnerów konsorcjum zainteresowanych konstruowaniem „aktywności możliwych” w odniesieniu do koncepcji analizy aktywności w związku z konstruowaniem podmiotów;

- drugi, przygotowany przez Izabelę Kamińską-Jatczak i Ewę Marynowicz-Hetkę, przedstawia główne linie wieloletniej współpracy Jeana-Marie Barbiera z Uniwersytetem Łódzkim, Katedrą Pedagogiki Społecznej. Ukazuje proces dochodzenia do uwspólniania podejścia epistemologicznego oraz liczne aktywności wokół kategorii: „Myśląc transformacje”, które przygotowały mentalnie autorów tego numeru do wspólnego i podzielanego myślenia na ten temat, nie zapominając jednak o dzielących ich różnicach.

Wspólna praca nad tym numerem tematycznym czasopisma „Nauki o Wychowaniu. Studia Interdyscyplinarne”, zderzanie się z różnymi punktami widzenia umożliwiły też transformacje reprezentacji samych autorów. Staraliśmy się zastosować takie metody pracy, które zapewniłyby transwersalność kulturową i międzynarodową komunikację naukową.

Zapraszamy do lektury!

\section{Bibliografia}

Barbier J.-M. (2016) Leksykon analizy aktywności. Konceptualizacje zwyczajowych pojęć, tłum. E. Marynowicz-Hetka, Łódź, Wydawnictwo Uniwersytetu Łódzkiego.

Barbier J.-M. (2017) Vocabulaire d'analyse des activités. Penser les conceptualisations ordinaires, Paris, Presses Universitaires de France.

Barbier J.-M., Durand M. (red.) (2018) Représenter/transformer, Débats en analyse des activités, współpraca C. Cohen, M.-L. Vitali, Paris, L’Harmattan. 
Jullien F. (2009) Les transformations silencieuses, Paris, Grasset.

Jullien F. (2017) Une seconde vie. Commencer véritablement d'exister, Paris, Grasset.

\section{Źródła internetowe}

Lavoisier A. (2001) Traktat podstawowy chemii, tłum. R. Mierzecki, http://bazhum.muzhp.pl/media//files/Analecta_studia_i_materialy_z_dziejow_nauki/ Analecta_studia_i_materialy_z_dziejow_nauki-r2001-t10-n1_(19)/Analecta_studia _i_materialy_z_dziejow_nauki-r2001-t10-n1_(19)-s7-122/Analecta_studia_i_materialy _z_dziejow_nauki-r2001-t10-n1_(19)-s7-122.pdf [dostęp: 2.04.2016].

\section{Cytowanie}

Barbier J.-M., Marynowicz-Hetka E. (2021) „Myśląc transformacje” - wprowadzenie w problematyke, „Nauki o Wychowaniu. Studia Interdyscyplinarne” 2(13), 15-19, https://doi.org/10.18778/2450-4491.13.02 